\title{
The Passing-on Problem in Damages and Restitution under EU Law \\ Magnus Strand
}

Reviewed by António Agostinho Guedes

The purpose of the book "is to analyse and to discuss the approach to the passing-on problem that has been chosen in the EU Law" (p. 19).

Passing-on refers to the cases where harm caused to a business is totally or partially passed on to encumber that business's customers or the next level of the supply chain. Passing-on may either be used as a defence (a "shield") by the defendant (arguing that the damages claimed by the claimant were passed on to its costumers), or as a ground (a "sword") by indirect claimants (the costumers to whom the damages were shifted) to claim damages from the defendant.

Thus, the "'passing-on problem' is not a distinct legal problem but a set of factual circumstances that triggers various legal problems" (p. 4), namely, three major legal issues: (i) who should have access to courts for purposes of bringing an action for damages or restitution, (ii) to what extent is a causal (or other) nexus required for the purposes of establishing causation or, in restitution, that the enrichment of the defendant is attributable to the disadvantage of the claimant, and (iii) how should awards of damages be estimated (that is, what heads of damages are available and to what extent should passing-on have an impact on the calculation of the award).

These three legal aspects are analysed in general, in order to assess the options available to every court seized with a passing-on situation, but also in the context of the three courses of action in which the passing-on problem has arisen under EU law, which are (i) damages from the EU under Article 340(2) of the Treaty on the Functioning of the European Union (TFEU), (ii) restitution from a Member State, and (iii) damages for breach of EU competition law.

* Professor at Porto Faculty of Law, Universidade Católica Portuguesa, 4169-005 Porto, Portugal. 
The book is divided into five parts.

Part I contains two chapters. First, a brief introduction to the passingon problem, beginning with an illustrative example followed by a description of the intended purpose of the book and of how the problem will be addressed (p. 3-23). The second chapter deals with the access to courts in general under EU law, that is, what conditions have to be met by the claimant to bring an action before the EU courts and which principles of EU law apply when an action is brought before the national courts - which would be the case where the action is brought against a Member State or a private entity (or individual). In this latter context, the author runs a thorough analysis of the principle of effective judicial protection, on the one hand, and of the principles of equivalence and effectiveness, on the other (p. 24-59).

Chapters 3 (Part II), 5 (Part III) and 7 (Part IV) constitute the main chapters of the book, where the passing-on problem is discussed in the context of the three relevant courses of action aforementioned.

Chapter 3 refers to the actions for non-contractual damages under Article 340(2) TFEU, that is, actions brought before the Court of Justice for damages caused by EU institutions or by their servants in the performance of their duties. After an introduction to Article 340(2) TFEU, the three legal aspects triggered by passing-on (access to court, substantive proximity and estimation of damages) are discussed and analysed in the context of these actions, both in general terms and specifically in relation to passing-on (p. 63-113). In chapter 4, the author explores other possible actions against the EU where the passing-on problem may arise, such as actions for restitution of sums unduly levied and unjust enrichment (p. 114-129).

Chapter 5 is dedicated to the actions brought against a Member State by reason of restitution of charges levied in breach of EU law. Again, in this new context, each of the abovementioned issues of access to court, proximity and estimation of damages is subjected first to some general observations and afterwards to a detailed analysis in relation to passing-on ( $\mathrm{p}$. 133-214). Chapter 6 deals with passing-on in actions for damages against a Member State, following the same structure of the previous chapters (p. 215-256).

The same approach is taken in chapter 7 , in what concerns actions whereby an individual (or private entity) claims damages for breach of EU competition law, here also taking into account Directive 2014/104/EU, 
which deals explicitly with the passing-on problem (p. 259-369). Chapter 8 discusses the possibility of other horizontal actions, separating EU law damages actions and EU law restitution actions (p. 370-397).

Finally, chapter 9 (Part V) "proceeds to summarize the analyses submitted in the previous chapters and to compare them" (p. 401), recovering some of the debated issues and adding some observations and suggestions about the issue of coordination of litigation (how to assure compensation to claimants from multiple levels of the supply avoiding multiple liability for defendants) and some considerations on deterrence and how it could work in the context of damage claims or restitutions (p. 401-429).

We are in the presence of a well-structured work, written in a clear and systematic way, easy to understand by any person with basic legal training.

Chapter 1 provides a clear view of the problem, of the legal questions involved therein and of the approach to be made in the subsequent chapters; Parts II (chapters 3 and 4), III (chapters 5 and 6) and IV (chapters 7 and 8) follow the same pattern in their structure. Each chapter begins with an outline of the same, followed by an introduction to the specific course of action considered; the author then proceeds to the analysis of each of the three major legal problems previously identified, beginning with some general observations and then discussing the problem regarding passing-on.

Each topic contains a description of the relevant case law of the EU courts, being the most important cases subjected to a detailed and exhaustive discussion, with mention to the relevant facts, analysis of the decision and of the court's reasoning and, sometimes, reference to the contribution of the Advocates General. At the same time, and when appropriate, the author refers to leading academic opinions. In chapter 7 (competition damages), the work is enriched with an interesting description of US antitrust law (on the topic of access to courts) and offers a comparative perspective of the issue under US law and EU law (p. 290-315).

It must be noted that the purpose elected by the author has led to an essentially descriptive approach, rather than a more discursive one. The conclusions at the end of the main chapters, especially chapter 9, are always brief and still somehow descriptive: "In this inquiry it has been endeavoured to find solutions that serve consistency in EU law, but it is apparent that the conclusions drawn in section 9.E rather suggest differentiation based on the character of the defendants, the private law distinction between restitution and damages, and the strength of public enforcement 
of EU law" (p. 425). The suggestions, which the author defines as a "modest proposal" (p. 427), refer mainly to policies designed to help solve the issues of coordination of litigation and deterrence through private enforcement.

Nevertheless, the final result is a systematic and extensive work on the passing-on problem, with essential information and guidance on each of the addressed topics, constituting a fundamental reference in the passingon problem under EU law. 